\title{
HCT116 Cells Cytotoxic Response to Multifuctionalized 5- Fluorouracil MWCNTs Conjugates In Colorectal Cancer
}

\author{
Hemalatha K.P. ${ }^{1}$, Suresh V. Kulkarni ${ }^{2}$, Manjunath K. ${ }^{3}$ \\ ${ }^{1}$ Assistant Professor, Department of Pharmaceutics, Sree Siddaganga College of Pharmacy, Tumkur-572102, Karnataka, India \\ ${ }^{2}$ Principal, Sree Siddaganga College of Pharmacy, Tumkur - 572102, Karnataka, India \\ ${ }^{3}$ HOD, Dept. of Pharmaceutics, Sree Siddaganga College of Pharmacy, Tumkur - 572102, Karnataka, India
}

\begin{abstract}
Nanomaterials are the foundations of Nanotechnology, which are measured in nanoscales, Carbon nanotubes are one of the interesting nanomaterials, studied for over 25 years because of their superlative properties such as high surface area, electrical and thermal conductivity, high biocompatibility, flexibility, resistance to corrosion and nanosize. According to research, carbon nanotubes are applied in sensing, water treatment, and drug delivery, mainly used to deliver the anticancer drugs. In our work, functionalization of multi walled carbon nanotubes done by covalent and non-covalent functionation methods, covalent functionalization showed better dispersing efficiency in aqueous medium and compatible with biological systems with damaging the crystal lattice of carbon nanotubes. Non covalent functionalization helps to derivatized with active compounds, surface adsorption or attachment of various molecules or antibodies, which subsequently helps in targeting the site and to produce therapeutic effects. Different formulations prepared by functionalized MWCNTs and multiple functionalization of MWCNTs done by binding the drug and antibodies to prepare functionalized MWCNTs 5-Fluorouracil complexes. The Cytotoxicity assay was carried out for the obtained new targeting formulations to analyze the effect of all the formulations on HCT116 cell line. The percentage death was determined based on the viability of the cells in the appropriate vehicle controls. In this study, we report the successful functionalization, binding of 5 Fluorouracil, antibodies to MWCNTs, and cells viability of all prepared formulations for the development of novel carbon based anticancer drug delivery system. Functionalized MWCNTs-5-Fluorouracil antibodies composite at concentration above $2.5 \mu \mathrm{g} / \mathrm{mL}$ exhibited $\geq 50 \%$ cytotoxicity post normalization with compound control to negate precipitation observed with the compound. All the formulations showed the precipitations indicating antitumor activity and biocompatibility.
\end{abstract}

KEYWORD: Bevacizumab antibodies, Cytotoxicity, Colorectal cancer, HCT116 Cells, Multiwalled carbon nanotubes

\section{INTRODUCTION}

Colorectal cancer (CRC) is a cancer that occurs in large intestine or rectum. CRC possess four stages, at higher stages cancer spread to other organs such as liver and lungs. Conventional treatment of anticancer drugs shows lot of systemic side effects to healthy tissues. Currently CRC is treated with surgery and radiation therapy, side effects of surgery include pain and tenderness, whereas radiation therapy cause fatigue and loose bowl movements. Among the neoplasm related deaths, CRC is numbered as third leading cause through worldwide. This might be due to considerable metastasis and drug resistance characteristics of CRC. Hence, in the recent years research was focused on to targeting of required drugs to colon region. Among the available new strategies of treatment of CRC, multimodal carbon nanotubes conjugates has provided promising cancer treatment approaches. All the limitations of conventional therapy, surgery and radiations can be overcome with the use of nanotechnology offered multifuntionalized nanoconjugates of anticancer drugs and monoclonal antibodies. Throughout worldwide many research groups are trying to bind anticancer drug to surface of nanotubes. ${ }^{1-3}$

Eventhough nanoparticles, dendrimers and liposomes have been tried to load and target anticancer drugs, carbon nanotubes (CNT) have been increasingly utilized in the field of cancer therapy. CNTs are made of looks tube like with a diameter of nanoscale. These are also named as 'King of nanomaterial' CNTs possess highest strength, excellent thermal conductivity, good biocompatibility, flexibility, moreover they can be tailored and functionalized. CNTs applications are extended to cancer treatment, hyperthermia induction, antibacterial therapy and tissue engineering. ${ }^{4,5} \mathrm{CNT}$ are fabricated by methods such as chemical vapour 


\section{International Journal of Current Science Research and Review}

ISSN: 2581-8341

Volume 04 Issue 08 August 2021

DOI: 10.47191/ijcsrr/V4-i8-08, Impact Factor: 5.825

IJCSRR@ 2021

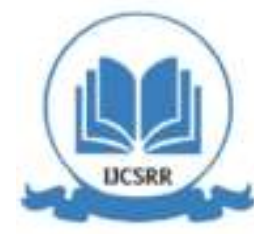

www.ijcsrr.org

deposition, electric arc method and laser deposition method. ${ }^{6}$ Based on number of carbon layers, CNTs are classified as single walled carbon nanotubes(SWCNTs), double walled carbon nanotubes (DWCNTs), and multiwalled carbon nanotubes (MWCNTS). CNTs can be functionalized either by covalent or non-covalent modifications. ${ }^{7-10}$ Covalent modifications is preferred because of its advantages with respect to solubility, safety and compatability. Currently the following three methods are preferred to functionalize MWCNTs. The methods are i) Initial acidic Treatment followed by treatment with Hcl ii) Treatment with Hcl iii) Initial basic Treatment followed by treatment with Hcl, ${ }^{11-16}$ However non covalent functionalization of MWCNTs is carried out using PEG polymer.

Pristine MWCNTs are uniform and stable but they are hydrophobic in nature. To develop drug loaded MWCNTs, solubility of MWCNTs in aqueous system is required after administration of drug delivery system, drug release, absorption and transportation. MWCNTs must possess characteristic properties such as solubility, stability, retainment in blood circulation. To achieve these properties, CNTs are functionalized. PEGylated MWCNTs enhances blood circulation of drug delivery system by reducing reticuloendothelial uptake. Once suitable functionalized MWCNTs are obtained these are loaded with anticancer drug and monoclonal antibodies. Bevacizumab is a recombinant humanized monoclonal antibody which is approved for use in metastatic colorectal cancer. It is also approved with 5-Fluorouracil based therapy for second line metastatic colorectal cancer. Bevacizumab acts by blocking angiogenesis by inhibiting vascular endothelial growth factor A (VEGF- A). In the present study, pristine MWCNTs are functionalized by covalent and non covalent methods. These functionalized MWCNTs are loaded with Bevacizumab and 5Fluorouracil individually and in combination. Anticancer activity of MWCNTs drug delivery system developed and cytotoxicity of all the formulations were evaluated using HCT116 cancer cells. HCT 116 is a human colon cancer cell line used in therapeutic research and drug screening.

\section{MATERIALS AND METHODS}

Multiwalled carbon nanotube (outer diameter 10-30 nm, number of walls 5-15, length 1-10 $\mu \mathrm{m}$ ) was purchased from Nano Wings Private limited, Telangana. 5-Fluorouracil was obtained as gift sample from Nantong Jinghua Pharmaceutical co.,ltd, Jiangsu, China. Methanol, Hydrochloric acid, Sulphuric acid, Nitric acid, Ammonium hydroxide (25\%), Hydrogen peroxide (30\%), PEG etc... are Laboratory grade, they were kind gift from Samarth life science private limited, Bevacizumab antibodies was a kind gift from Biocon Biopharmaceuticals, Bommasandra, Bangalore. HCT116 cells cultured and MTT Assay were carried out at Anthem Biosciences, Bangalore.

\section{Functionationalization of MWCNTs followed by binding of 5- Fluorouracil ${ }^{17-19}$}

a) Covalent functionalization done by initial acidic treatment followed by treatment with hydrochloric acid: Initial acidic treatment given to MWCNTs by using $\mathrm{HNO}_{3}$ and $\mathrm{H}_{2} \mathrm{SO}_{4}$, which leads to produce oxidized MWCNTs. The produced oxidized MWCNTs were treated with $\mathrm{HCl}$ which gives rise to carboxylated MWCNTs. Take $250 \mathrm{mg}$ of MWCNTs and $100 \mathrm{ml}$ mixture of $65 \% \mathrm{HNO}_{3}$ and $98 \% \mathrm{H}_{2} \mathrm{SO}_{4}(\mathrm{~V}: \mathrm{V}=1: 3)$ in a flask, were mixed thoroughly, agitated for $12 \mathrm{~h}$ in agitator for $12 \mathrm{~h}$ at room temperature. Washed the product with fresh water to obtain oxidized MWCNTs. Immersed the obtained oxidized MWCNTs in Hcl and reflux for 24h, then filtered to obtain carboxylated MWCNTs, washed with water until to neutral $\mathrm{pH}$ and dried overnight in vacuum oven at $40{ }^{\circ} \mathrm{C}$.

b) Non covalent functionalization done by taking $1 \mathrm{~g}$ of PEG 4000 dissolved in $10 \mathrm{ml}$ of water, $500 \mathrm{mg}$ of pristine MWCNTs and PEG solution were taken torson test tube and subjected to sonicator for 15 mins with the help of a fast clean ultrasonic bath sonicator. Removal of agglomerates of unbound PEG done by centrifugation method performed at $7000 \mathrm{RPM} / 5 \mathrm{~min}$ where only the supernatant was retained and filtration done through 0.2 micro filter (Millipore) through vacuum filter and PEG functionalized MWCNTs were dried in room temperature.

c) Binding of 5-Fluorouracil and Bevacizumab antibodies to functionalized MWCNTs: 5- Fluorouracil solution (5- Fluorouracil in methanol $1 \mathrm{mg} / \mathrm{ml}$ ) was prepared and dispersed in covalent and noncovalent functionalized MWCNTs and formulations are numbered as shown in table 1. Functionalized MWCNTs were dispersed in 5-Fluorouracil solution (5-Fluorouracil in methanol \{1 $\mathrm{mg} / \mathrm{ml}\}$ ) at varied concentrations as given in table 1 and sonicated for 10 minutes. Subsequently, the dispersion is rotated for 16 hour by using rotor to facilitate loading of 5-Fluorouracil. Thereafter, the mixture was subjected to centrifugation at $3000 \mathrm{rpm}$ for 10 minutes and then washed with methanol and followed by deionised water three times and centrifuged to remove free/unbound 


\section{International Journal of Current Science Research and Review}

ISSN: 2581-8341

Volume 04 Issue 08 August 2021

DOI: 10.47191/ijcsrr/V4-i8-08, Impact Factor: 5.825

IJCSRR@ 2021

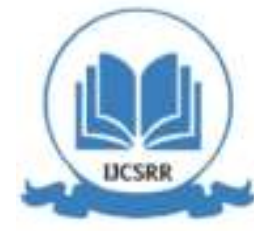

www.ijesrr.org

drug. The supernatant was collected, whereas the solid samples were dried at $30^{\circ} \mathrm{C}$ in a vacuum oven for 24 hours to obtain different formulations.

Pristine MWCNTs were functionalized by means of covalent functionalization, non- Covalent Functionalization, covalent functionalization followed by non - Covalent functionalization, the drug 5-Fluorouracil binded to above three types of functionalized MWCNTs. Bevacizumab antibodies were loaded on to MWCNTs Covalent and Non-Covalent functionalized 5-Fluorouracil conjugate. Cell cytotoxicity properties of all formulations given Table 2 were evaluated using MTT proliferation assay using HCT116 cancer cells in order to determine the anticancer effects of the nanoconjugates invitro.

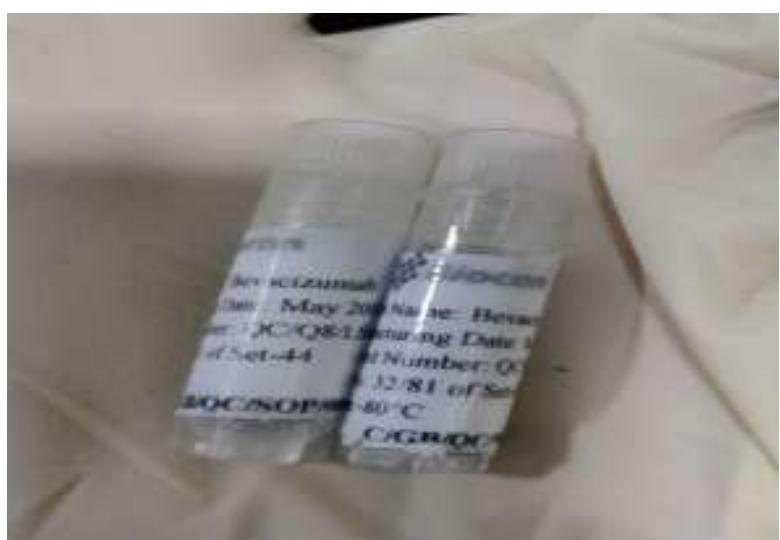

Figure 1. Bevacizumab Antibodies

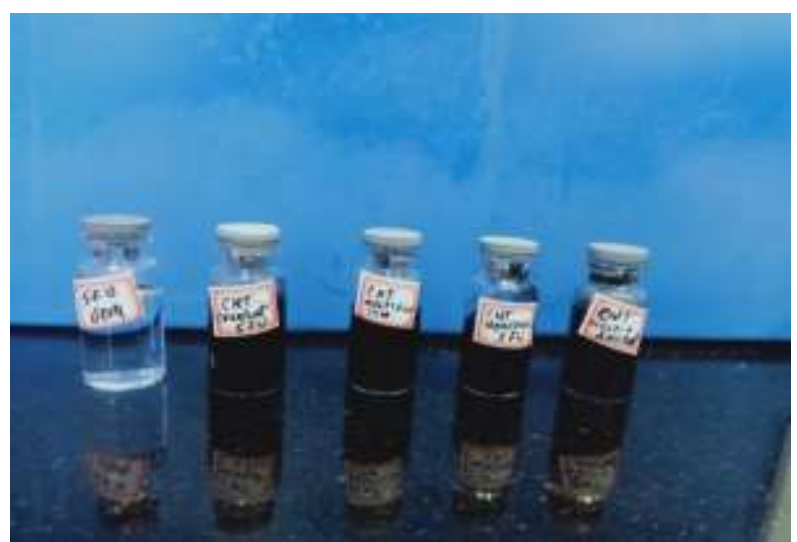

Figure 2. MWCNTs formulations

Table 1. 5-Fluorouracil formulations

\begin{tabular}{|c|c|c|c|c|}
\hline Formulations & & Functionalization & Drug & Antibodies \\
\hline $\mathrm{F} 1$ & Control & - & $\begin{array}{l}\text { Fluorouracil } \\
\text { (Control) }\end{array}$ & - \\
\hline $\mathrm{F} 2$ & Control & - & - & $\begin{array}{l}\text { Bevacizumab } \\
\text { antibodies (control) }\end{array}$ \\
\hline F3 & \multirow{4}{*}{ MWCNTs } & $\begin{array}{l}\text { Covalent } \\
\text { Functionalization }\end{array}$ & 5-Fluorouracil & - \\
\hline $\mathrm{F} 4$ & & $\begin{array}{l}\text { Non- Covalent } \\
\text { Functionalization }\end{array}$ & 5-Fluorouracil & - \\
\hline F5 & & $\begin{array}{l}\text { Covalent +Non- } \\
\text { covalent } \\
\text { Functionalization }\end{array}$ & 5-Fluorouracil & - \\
\hline F6 & & $\begin{array}{l}\text { Covalent +Non- } \\
\text { covalent } \\
\text { Functionalization }\end{array}$ & 5-Fluorouracil & $\begin{array}{l}\text { Bevacizumab } \\
\text { antibodies }\end{array}$ \\
\hline
\end{tabular}

\section{Preparation of Functionalized MWCNTs formulation for cell viability assay}

In the present study, all formulations were processed as mentioned in table 1 and 2, prepared compounds were used to treat the HCT cells each time. All formulations given in table were prepared separately in PBS solution. A stock concentration of each compound was sonicated for 15 minutes and subsequently diluted to the required doses via serial dilutions. For further dispersion, the formulations were vortex agitated for 2 minutes briefly prior to cell treatment. The suspensions of the test materials with different doses were immediately added to the cells and incubated for 72 hours to assess cytotoxicity. 


\section{International Journal of Current Science Research and Review}

ISSN: 2581-8341

Volume 04 Issue 08 August 2021

DOI: 10.47191/ijcsrr/V4-i8-08, Impact Factor: 5.825

IJCSRR @ 2021

www.ijcsrr.org

\section{Cytotoxicity assay ${ }^{20-23}$}

Cytotoxicity assay was carried out to analyze the effect of the compounds on HCT116 cells. The cells were treated with the compound for 72 hours at $37{ }^{\circ} \mathrm{C}$ with $5 \% \mathrm{CO}_{2}$. MTT reagent was used to measure the cytotoxicity. The percentage death was determined based on the viability of the cells in the appropriate vehicle control; by considering the growth in the presence of vehicle control (VC) as $100 \%$.

\section{Cell Culture}

Cells will be revived, cultured and maintained to a confluency of $80 \%$ to $90 \%$ in T-25 and T-75 flasks. For testing the cytotoxicity of compounds, the cells will be seeded in 96 well plate at a density of 104 cells / well for overnight at $37{ }^{\circ} \mathrm{C}$ with $5 \% \mathrm{CO}_{2}$. Compound will be added with 7 concentrations of drug (as specified by the client) and a vehicle control ( 0 concentration of compound) and the plates will be incubated $37^{\circ} \mathrm{C}$ with $5 \% \mathrm{CO}_{2}$ overnight. After 24 hours' incubation, the plates will be treated with resazurin (Alamar blue) or equivalent reagent (MTT) for 3 hours to determine the viability of cell. The percentage viability will be determined based on the viability of the cells in the appropriate vehicle controls, by considering the growth in the vehicle control as $100 \%$. Cell viability will be evaluated $0-8$ dilutions in triplicates/drug/cell line at one-time point, in a single trial usi $\mu \mathrm{g}$ tetrazolium salts or resazurin or equivalent. Tumor cell growth is most evident and maintained a level of rapid growth. Details of the optimized final protocol will be reflected in the report. MMS will be used as positive control.

\section{1: Seeding of HCT116}

a. Cells were seeded in a 96-well plate and incubated till the cells were adhered.

b. Seeding density: 10,000 cells/well

\section{2: Drug addition}

c. Cells were treated with $10 \mu \mathrm{L}$ of the compounds / MMS (Semi log dilutions).

d. Cells treated with only Milli Q water and culture medium were maintained as vehicle control for the compound and MMS respectively. The plate was incubated for 72 hours at $37^{\circ} \mathrm{C}$ with $5 \% \mathrm{CO}_{2}$

\section{3: Reading}

a. $20 \mu \mathrm{L}$ of MTT $(1 \mathrm{mg} / \mathrm{mL})$ was added to each well and incubated for 3 hours at $37^{\circ} \mathrm{C}$ with $5 \% \mathrm{CO}_{2}$.

b. Medium containing MTT was completely removed from each well and was added with $100 \mu \mathrm{L}$ of $100 \%$ DMSO. The absorbance was measured at $570 \mathrm{~nm}$ to detect the cell viability and cell death.

Table 2. Details of Stock Concentration of all 5-Flurouracil formulations

\begin{tabular}{|l|l|l|l|}
\hline Sl. No. & Compound & $\begin{array}{l}\text { Stock } \\
\text { concentration }\end{array}$ & $\begin{array}{l}\text { Solvent used to make the stock and working } \\
\text { concentration }\end{array}$ \\
\hline 1 & 5 - Fluorouracil (Control) & $50 \mathrm{mg} / \mathrm{mL}$ & Milli Q water \\
\hline 2 & MWCNTS Covalent functionalized 5-FU Conjugate & $50 \mathrm{mg} / \mathrm{mL}$ & Milli Q water \\
\hline 3 & MWCNTS Non-Covalent functionalized 5-FU Conjugate & $50 \mathrm{mg} / \mathrm{mL}$ & Milli Q water \\
\hline 4 & $\begin{array}{l}\text { MWCNTS Covalent and Non-Covalent functionalized 5- } \\
\text { FU Conjugate }\end{array}$ & $50 \mathrm{mg} / \mathrm{mL}$ & Milli Q water \\
\hline 5 & Antibody & $2 \mu \mathrm{g} / \mathrm{mL}$ & Milli Q water \\
\hline 6 & $\begin{array}{l}\text { MWCNTS Covalent and Non-Covalent functionalized 5- } \\
\text { Flurouracil (Control) + Antibody }\end{array}$ & $2 \mu \mathrm{mg} / \mathrm{mL} /+$ & Milli Q water \\
\hline 7 & MMS (Positive control) & $11.68 \mathrm{M}$ & Cell Culture medium \\
\hline
\end{tabular}




\section{International Journal of Current Science Research and Review}

ISSN: 2581-8341

Volume 04 Issue 08 August 2021

DOI: 10.47191/ijesrr/V4-i8-08, Impact Factor: 5.825

IJCSRR@ 2021

www.ijjcsrr.org

\section{Observation:}

I . Cytotoxicity studies of 5- Fluorouracil formulations
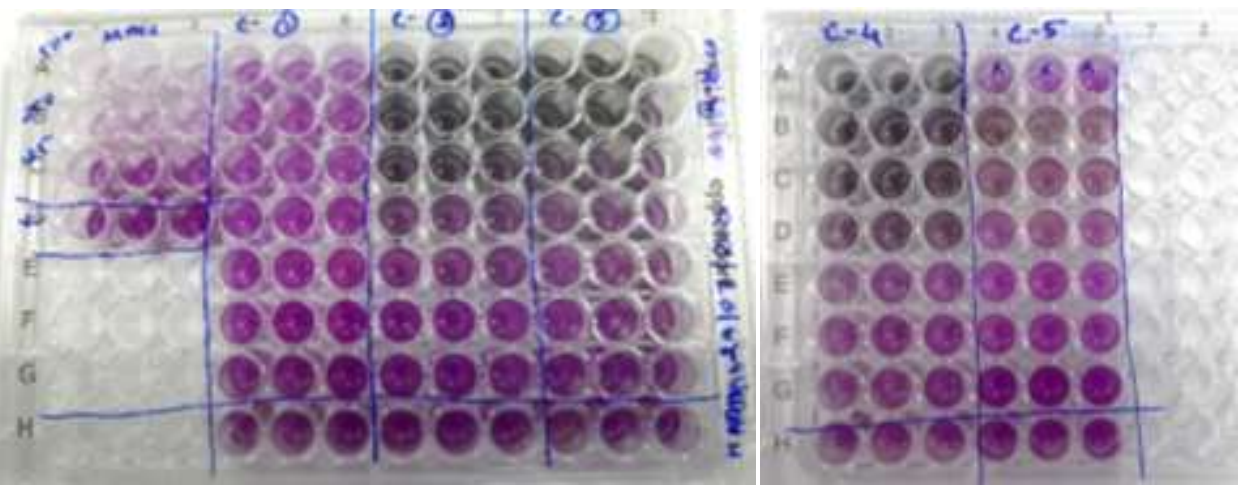

Figure 3. Precipitation observed in plates after the treatment of 5-Fluorouracil formulations

Table 3. Compound concentration treated with HCT 116 cells

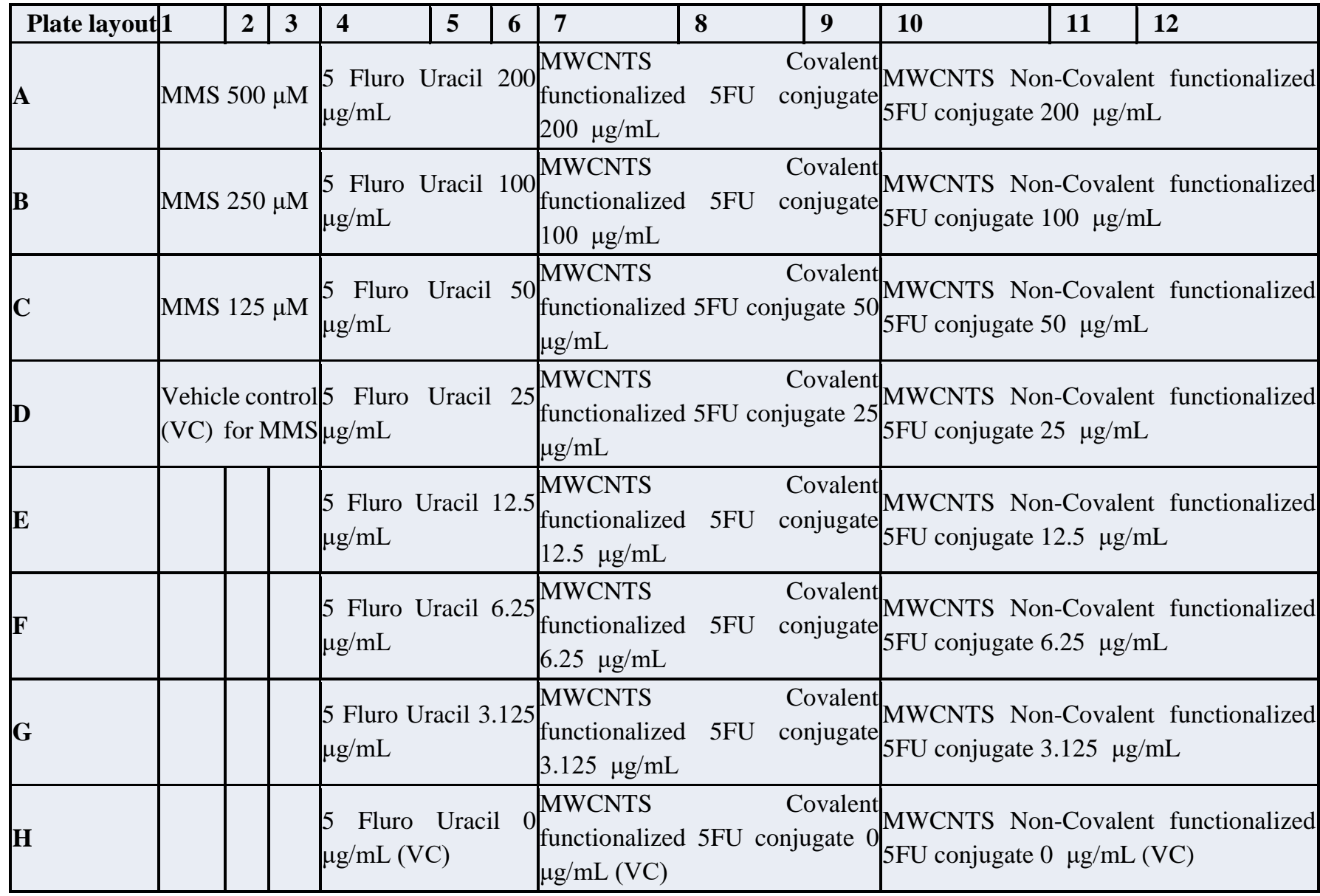


International Journal of Current Science Research and Review

ISSN: 2581-8341

Volume 04 Issue 08 August 2021

DOI: 10.47191/ijcsrr/V4-i8-08, Impact Factor: 5.825

IJCSRR @ 2021

www.ijesrr.org

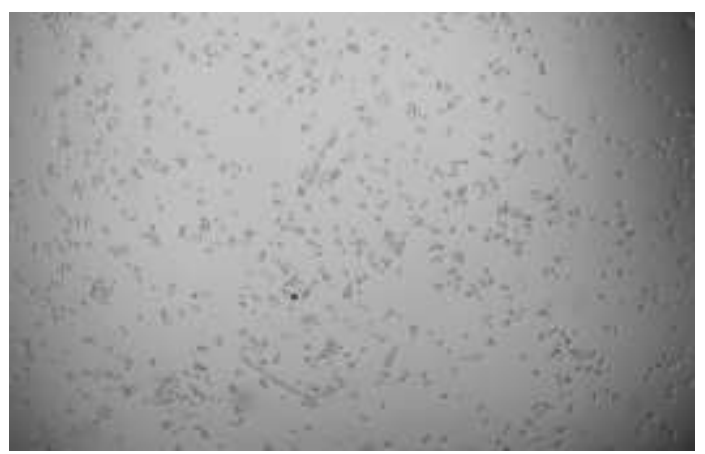

a) $500 \mu \mathrm{g} / \mathrm{mL}$ Precipitation observed

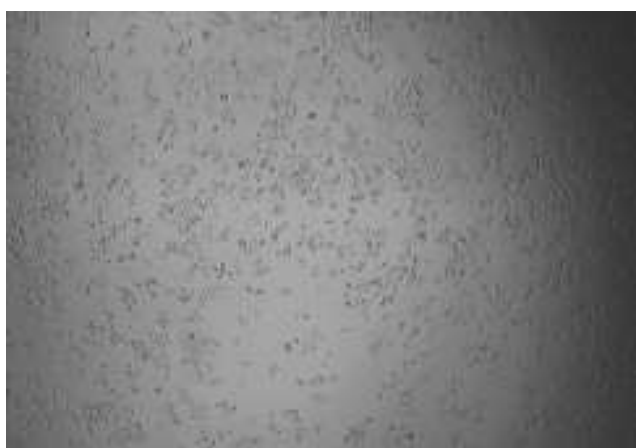

b) Vehicle Control (Cell culture medium)

Figure 4. Cytotoxic images of MMS on HCT116 and Vehicle control

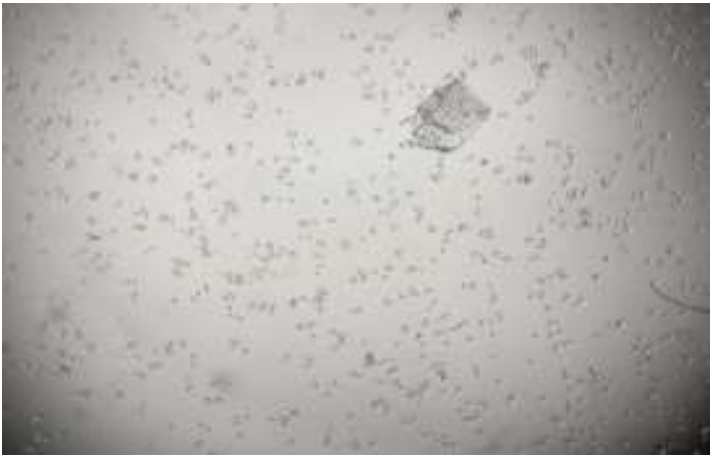

a) $5000 \mu \mathrm{g} / \mathrm{mL}$ Precipitation observed

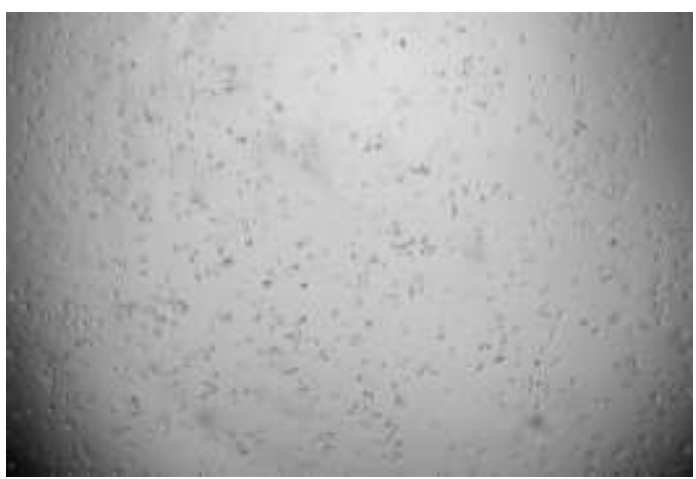

c) $1250 \mu \mathrm{g} / \mathrm{mL}$ Precipitation observed

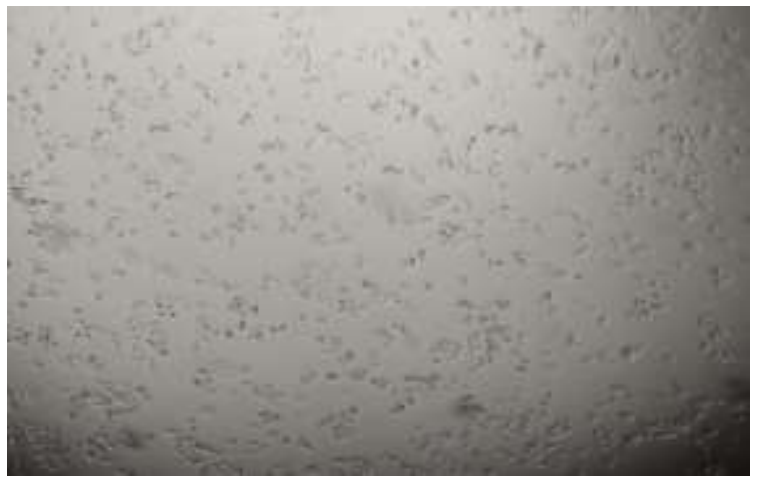

e) $313 \mu \mathrm{g} / \mathrm{mL}$ Precipitation observed

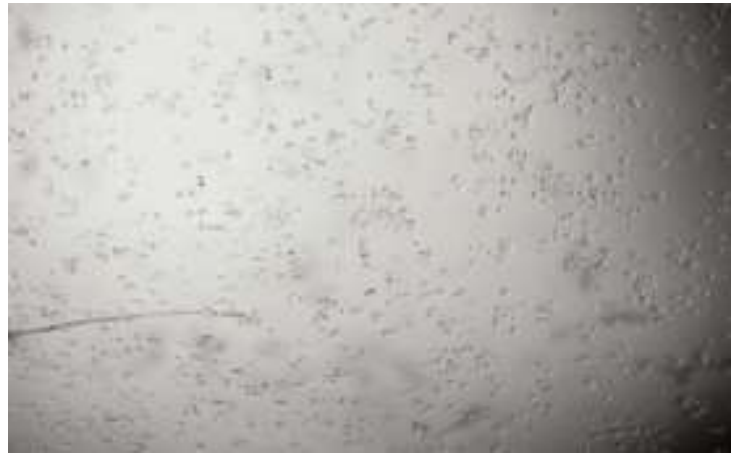

b) $2500 \mu \mathrm{g} / \mathrm{mL}$ Precipitation observed

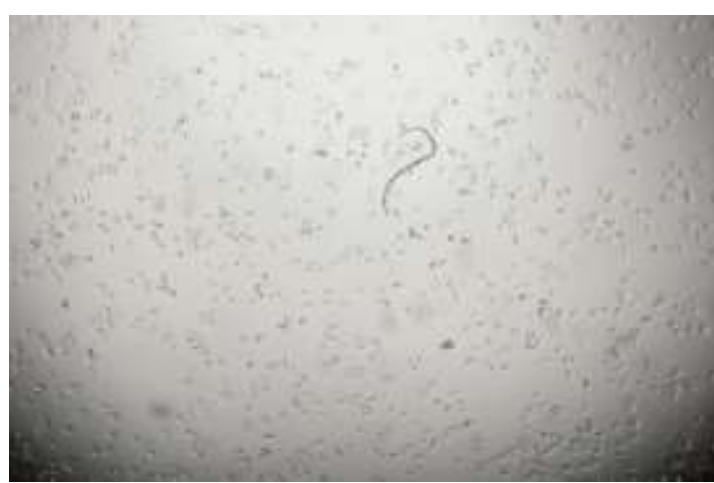

d) $625 \mu \mathrm{g} / \mathrm{mL}$ Precipitation observed

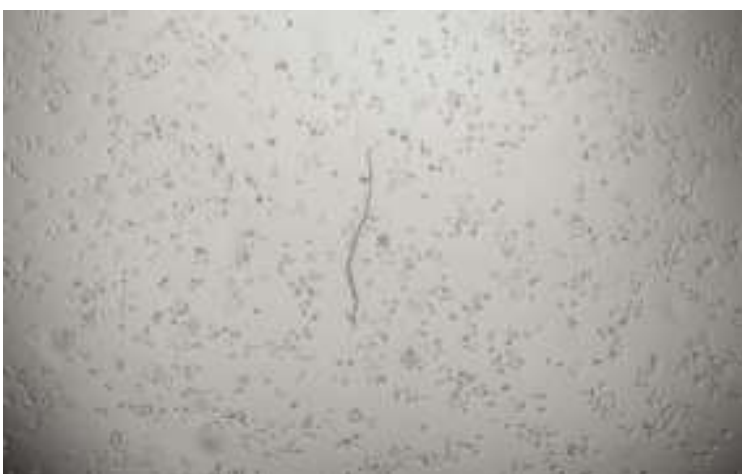

f) $156 \mu \mathrm{g} / \mathrm{mL}$ Precipitation observed 


\section{International Journal of Current Science Research and Review}

ISSN: 2581-8341

Volume 04 Issue 08 August 2021

DOI: 10.47191/ijesrr/V4-i8-08, Impact Factor: 5.825

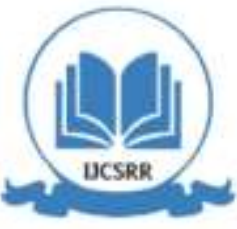

www.ijjcsrr.org

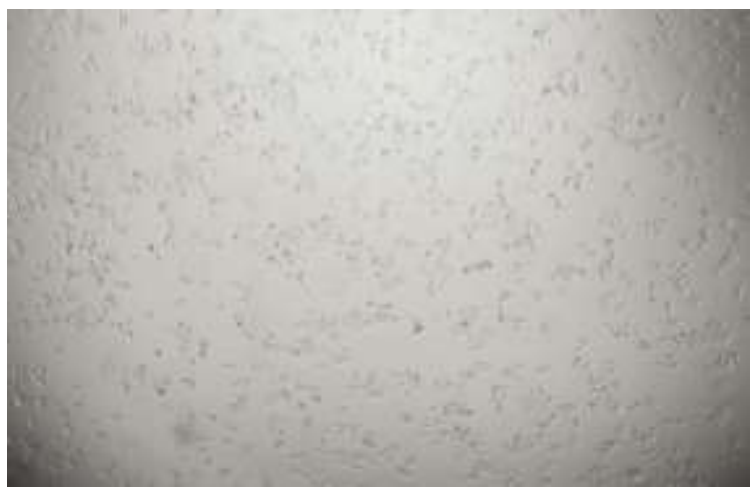

g) $78 \mathrm{~g} / \mathrm{mL}$ Precipitation observed

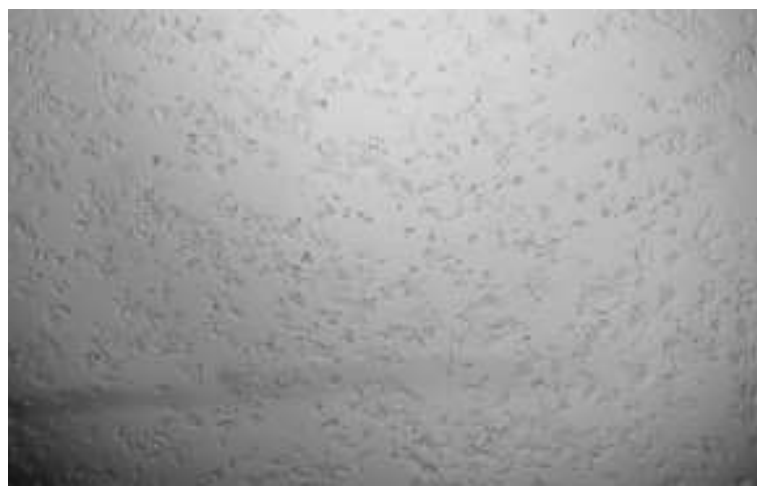

h) Vehicle Control (Distilled Water)

Figure 5(a to h). Cytotoxic images of 5-Fluorouracil at different concentration on HCT116

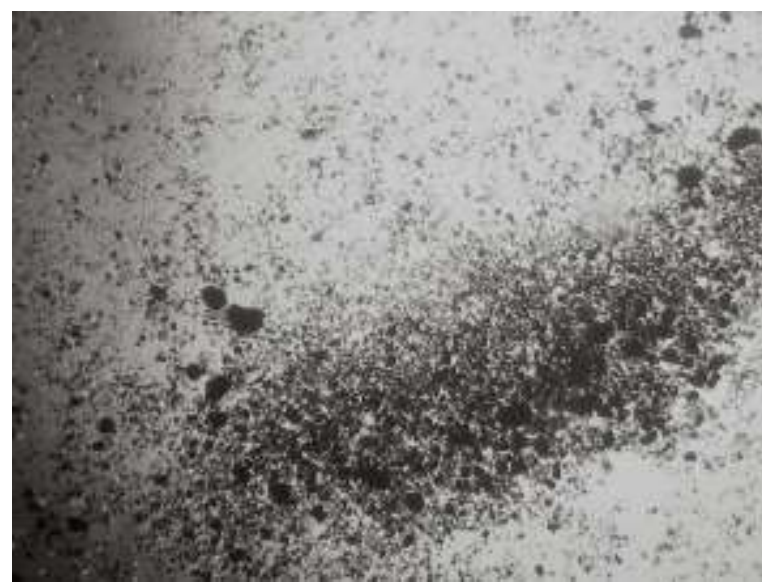

a) $5000+20 \mu \mathrm{g} / \mathrm{mL}$ Precipitation observed

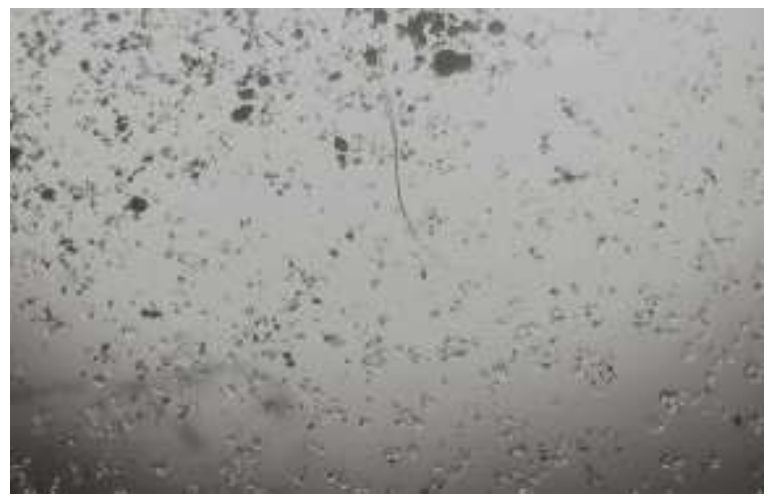

c) $1250+5 \mu \mathrm{g} / \mathrm{mLPrecipitation} \mathrm{observed}$

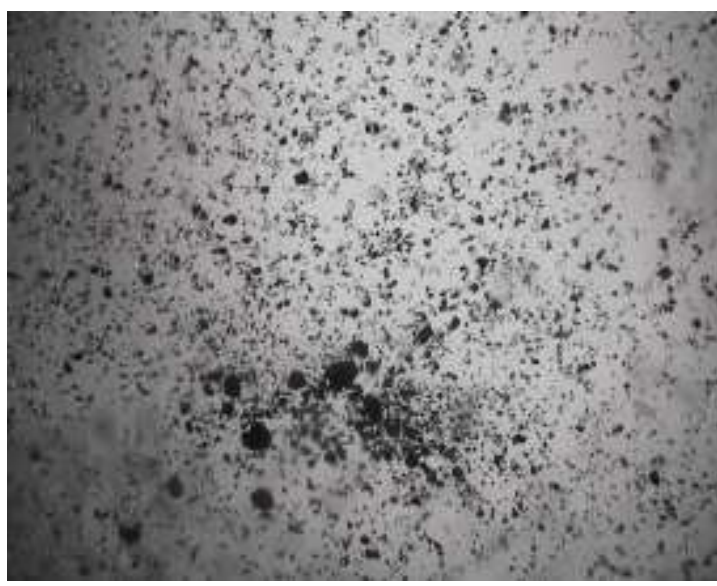

b) $2500+10 \mu \mathrm{g} / \mathrm{mL}$ Precipitation observed

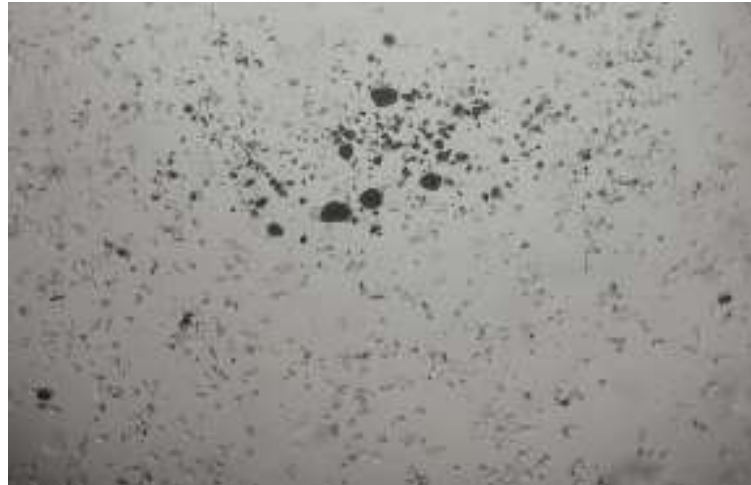

d) $625+2.5 \mu \mathrm{g} / \mathrm{mL}$ Precipitation observed 


\section{International Journal of Current Science Research and Review}

ISSN: 2581-8341

Volume 04 Issue 08 August 2021

DOI: 10.47191/ijcsrr/V4-i8-08, Impact Factor: 5.825

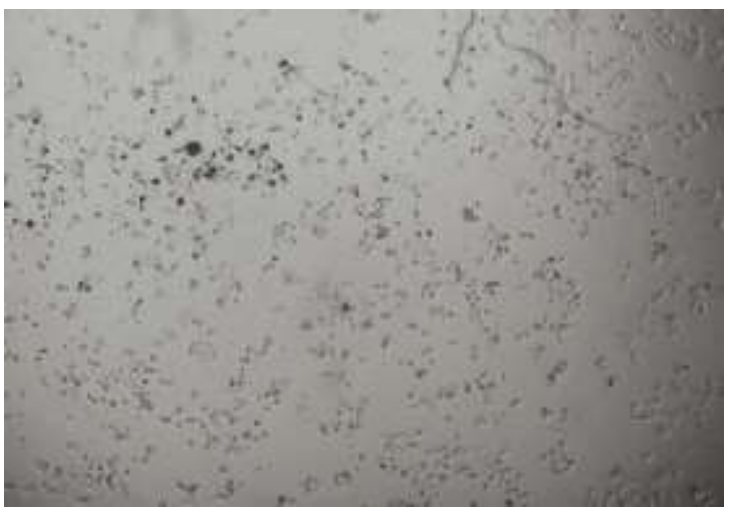

e) $313+1.3 \mu \mathrm{g} / \mathrm{mL}$ Precipitation observed

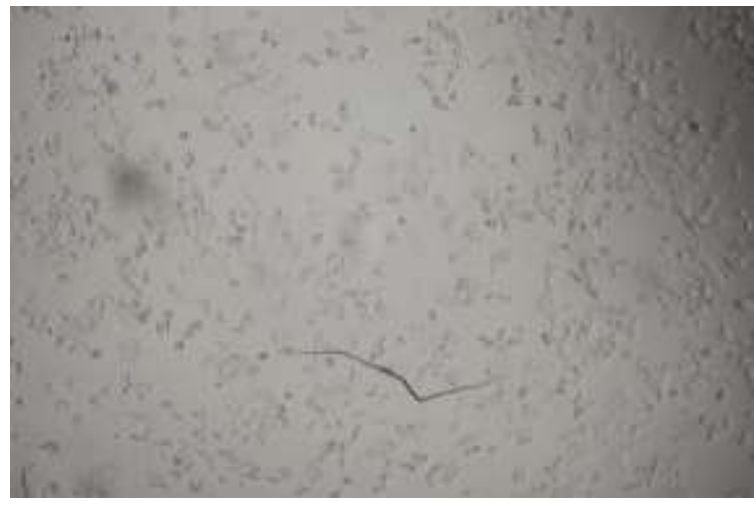

g) $78+0.3 \mu \mathrm{g} / \mathrm{mL}$ Precipitation observed

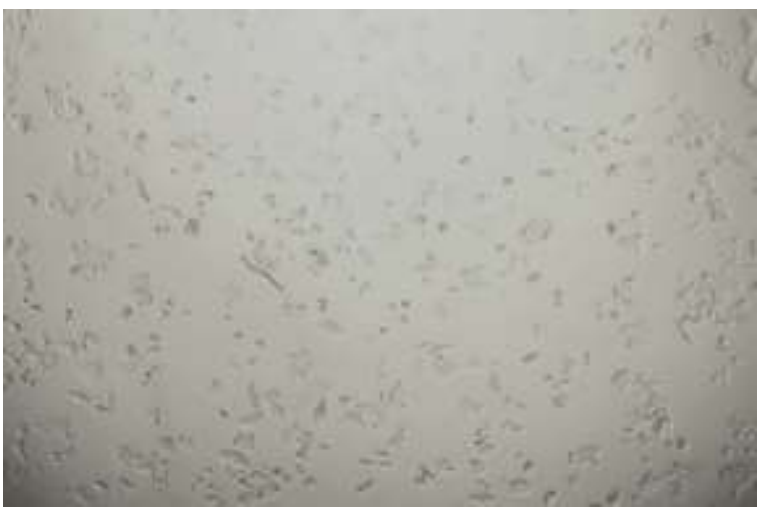

f) $156+0.6 \mu \mathrm{g} / \mathrm{mL}$ Precipitation observed

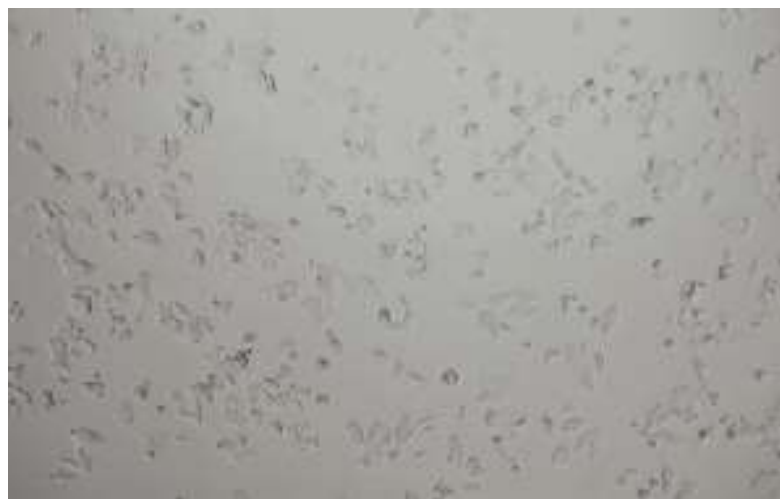

h) Vehicle Control (Distilled Water)

Figure 6 (a to h). Cytotoxic images of Covalent and Non covalent functionalized 5-Fluorouracil Bevacizumab Antibodies conjugate at different concentration on HCT116 cells

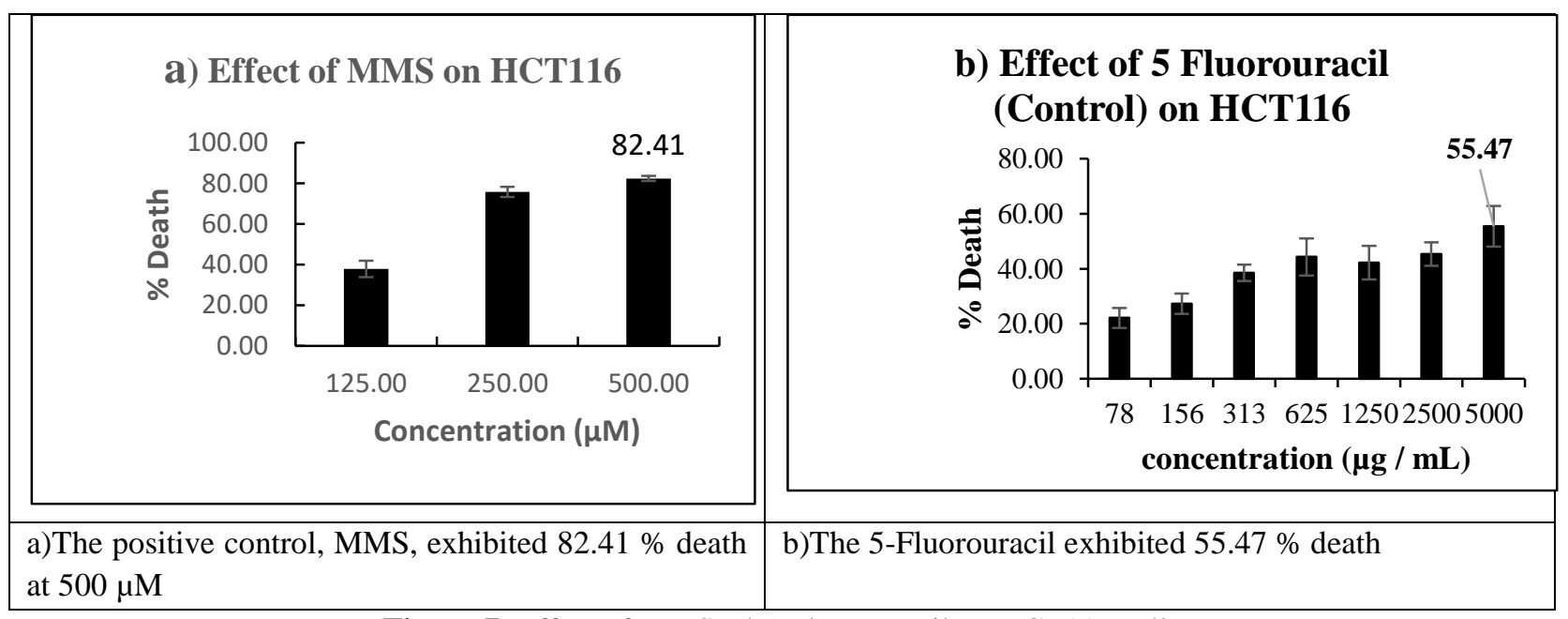

Figure 7. Effect of MMS ad 5-Fluorouracil on HCT116 cells 
International Journal of Current Science Research and Review

ISSN: 2581-8341

Volume 04 Issue 08 August 2021

DOI: 10.47191/ijcsrr/V4-i8-08, Impact Factor: 5.825

IJCSRR @ 2021

www.ijesrr.org

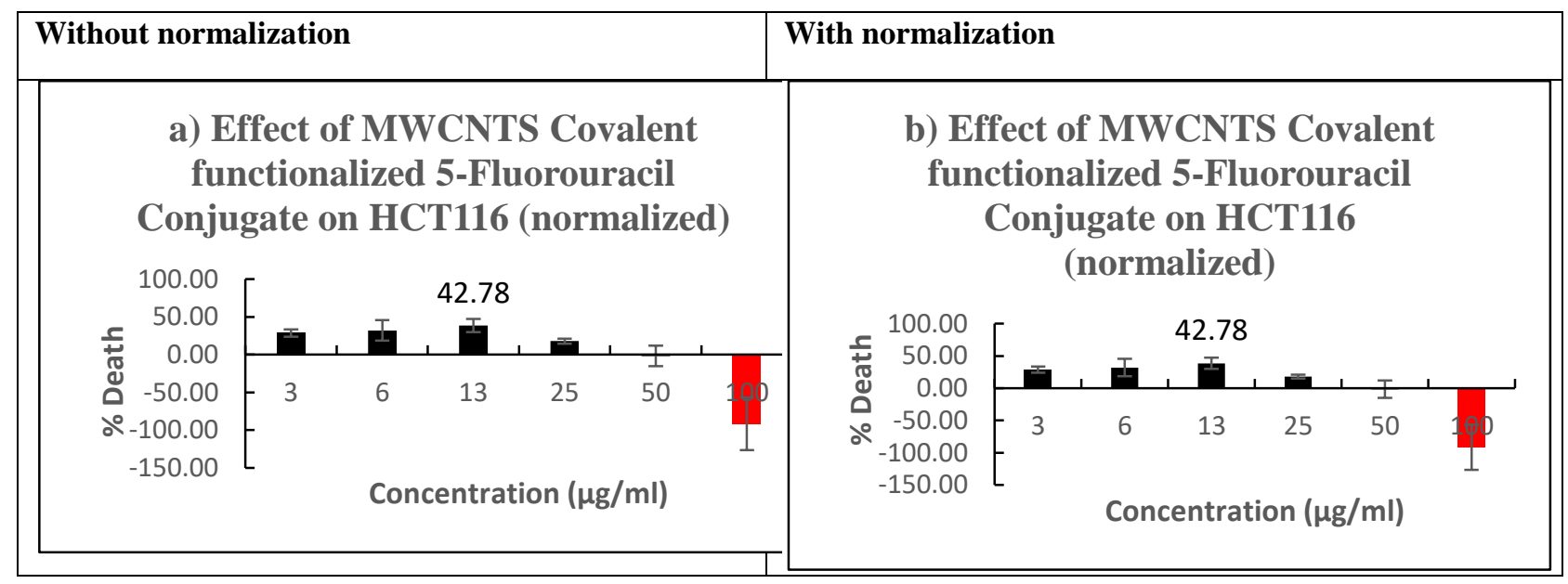

Figure 8. Cytotoxic graph of MWCNTS Covalent functionalized 5-Fluorouracil Conjugate on HCT116 cells

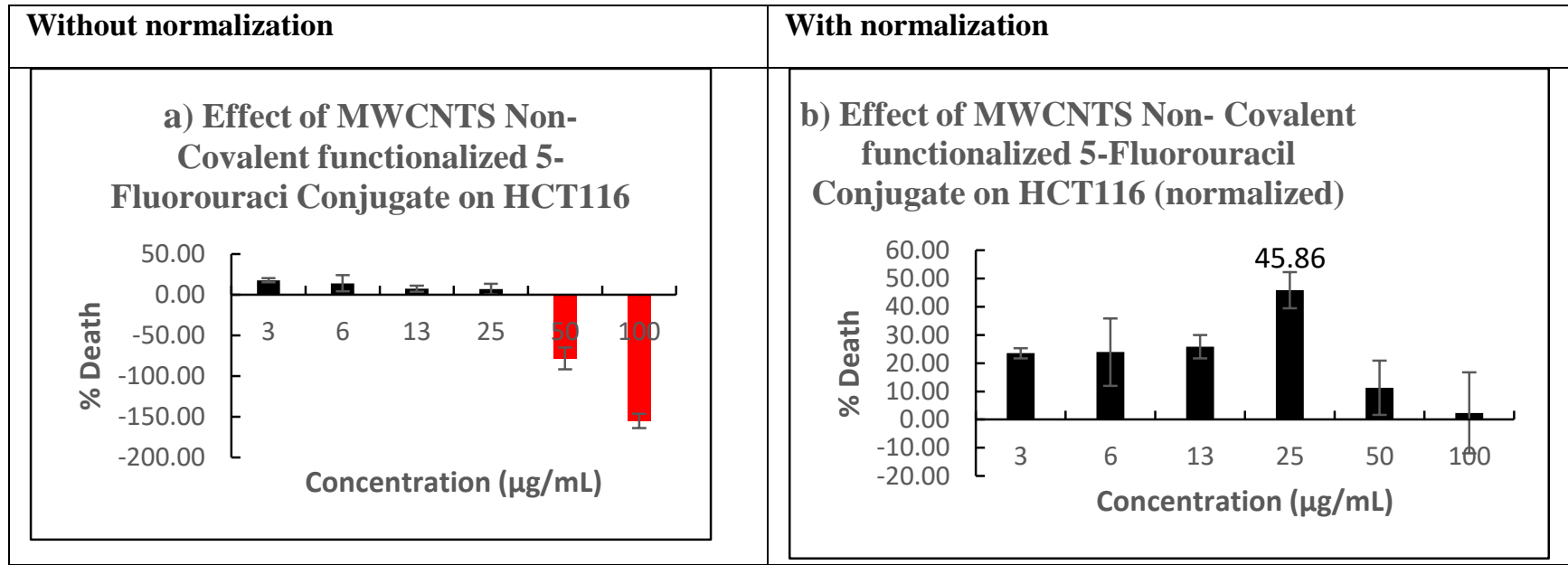

Figure 9. Cytotoxicity graph of MWCNTS Non-Covalent functionalized 5-Fluorouracil Conjugate on HCT116 cell

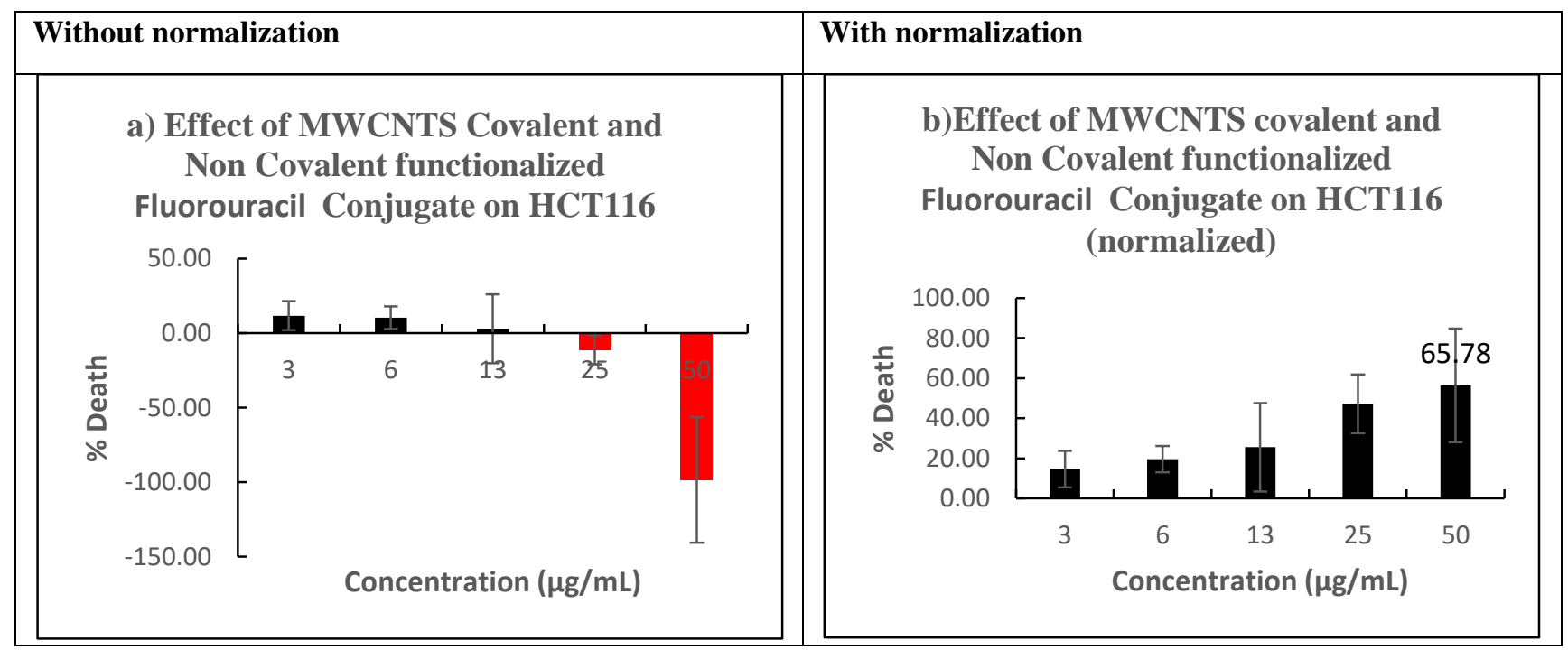

Figure 10. Cytotoxicity graph of MWCNTS Covalent and Non-Covalent functionalized 5-Fluorouracil Conjugate on HCT116 cells 
ISSN: 2581-8341

Volume 04 Issue 08 August 2021

DOI: 10.47191/ijcsrr/V4-i8-08, Impact Factor: 5.825

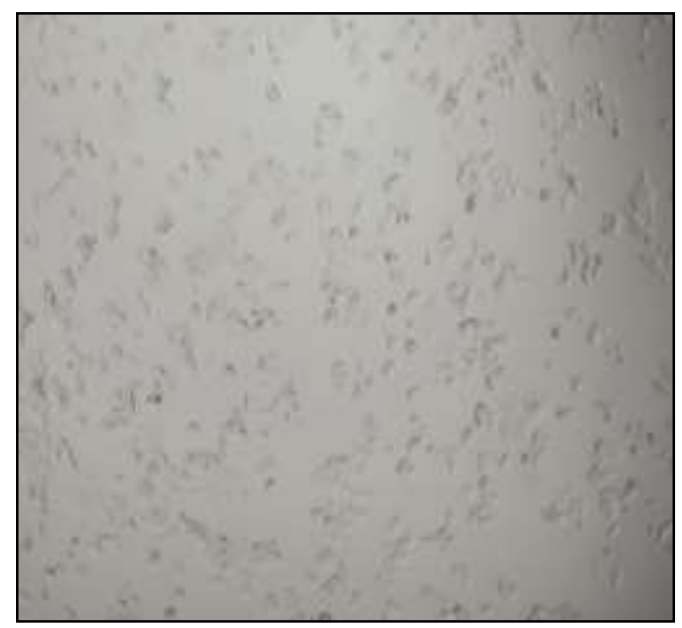

a) Images of antibodies with the cells no precipitation observed

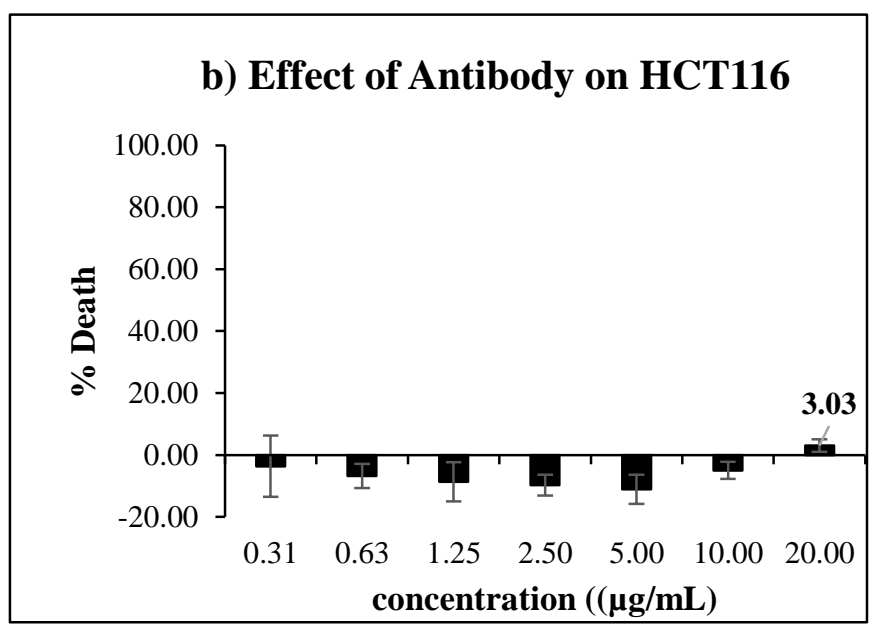

b) Effect of Antibody on HCT116 cells

Figure 11. Cytotoxic images and graph of Bevacizumab Antibodies on HCT116 Cells

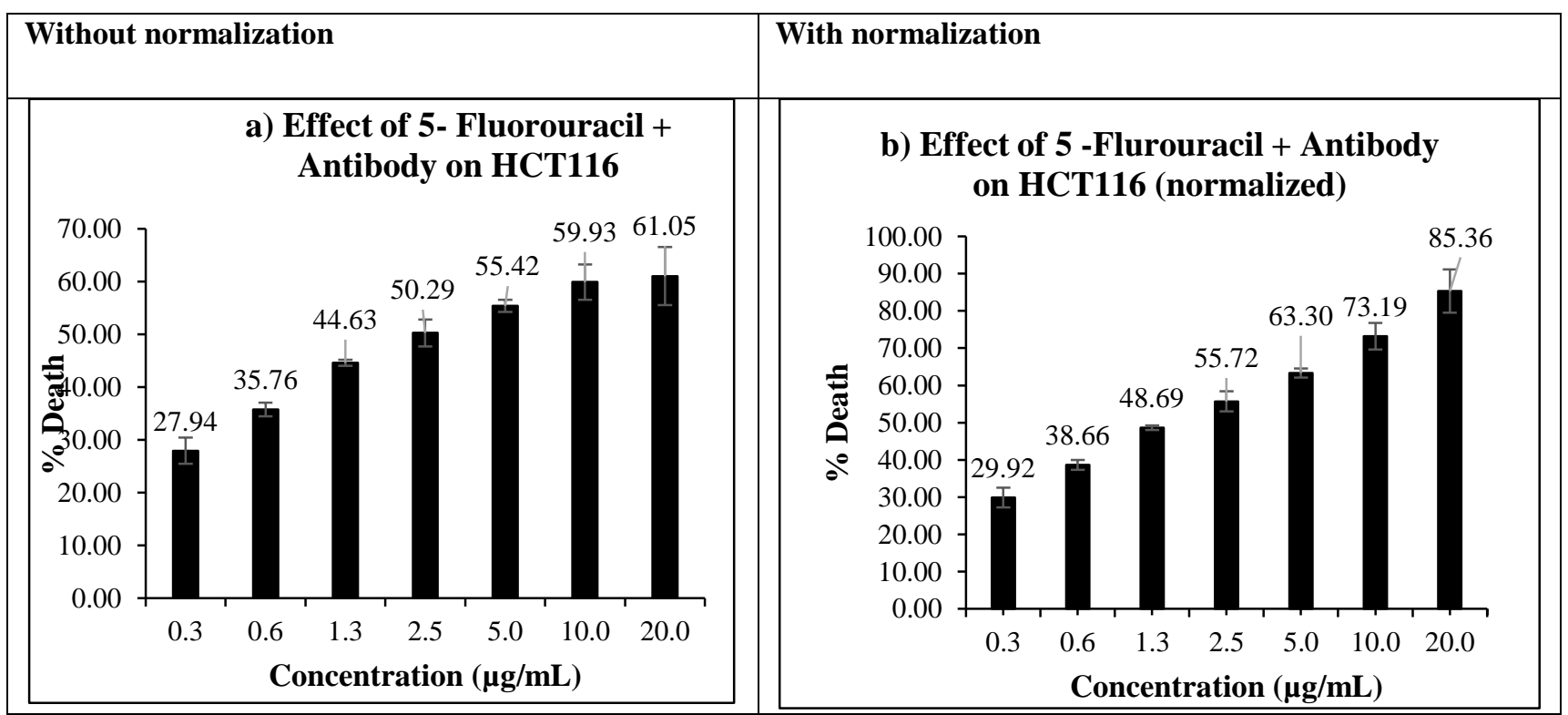

Figure 12. Cytotoxicity graph of Covalent and Non covalent functionalized 5- Fluorouracil Bevacizumab Antibodies conjugate on HCT116 cells

\section{CONCLUSION}

The considerable research and development of nanomaterials in the treatment of cancer. CNTs employed as anticancer drug carriers. The all formulation conjugates were tested for cytotoxicity on HCT116 cells. MMS was used as the positive control.MMS demonstrated an $82.41 \%$ death at a concentration of $500 \mu \mathrm{g} / \mathrm{mL}$ image given in figure $4 \mathrm{a}$ and graph depicted in figure $7 \mathrm{a}$. Vehicle control cell image depicts in figure 4b. The 5-Fluorouracil control exhibited dose dependent cyto toxicity at 8 different dilutions and cell viability or precipitation images shown in figures 5a to 5h. 5-Fluorouracil control demonstrated 55.47 \% death depicted in figure $7 \mathrm{~b}$. After the treatment with all the prepared compounds in plates the precipitation observed depicted in figure 3 . The pprecipitation was observed in all concentrations for test compounds except Bevacizumab Antibodies control. No significant Cell Death was observed at highest tested concentration of Antibodies. Cytotoxic images and effect of Bevacizumab Antibodies graph 


\section{International Journal of Current Science Research and Review}

ISSN: 2581-8341

Volume 04 Issue 08 August 2021

DOI: 10.47191/ijcsrr/V4-i8-08, Impact Factor: 5.825

IJCSRR @ 2021

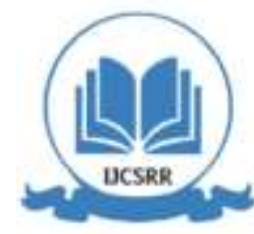

www.ijcsrr.org

on HCT116 Cells given in 11a and 11b. Therefore, the values were normalized with the absorbance values of compounds serially diluted (compound control). MWCNTs Covalent functionalized 5-FU conjugate was cytotoxic at $13 \mu \mathrm{g} / \mathrm{mL}$ post normalization with compound only control to negate precipitation observed with the compound. Cytotoxic effect graphs of MWCNTS Covalent functionalized 5-FU Conjugate on HCT116 cells with out and with normalization given in figures 8a and 8b respectively. Precipitation was observed and was found to interfere with the measurement of absorbance. The values were normalized with the absorbance values of the compound control and graph was plotted. Cytotoxicity of MWCNTs Covalent functionalized 5-FU conjugate was observed at $13 \mu \mathrm{g} / \mathrm{mL}$ and exhibited $42.78 \%$ cell death. MWCNTs Non-Covalent functionalized 5-FU conjugate was cytotoxic at $25 \mu \mathrm{g} / \mathrm{mL}$ post normalization with compound only control to negate precipitation observed with the compound. Cytotoxic effect graph of MWCNTS Non-Covalent functionalized 5-FU Conjugate on HCT116 cells with out and with normalization given figure $9 \mathrm{a}$ and $9 \mathrm{~b}$ respectively. Precipitation was observed and was found to interfere with the measurement of absorbance. The values were normalized with the absorbance values of the compound control and graph was plotted. Cytotoxicity of MWCNTs Non-Covalent functionalized 5-FU conjugate was observed at 25 $\mu \mathrm{g} / \mathrm{mL}$ and exhibited $45.86 \%$ cell death. MWCNTs Covalent and Non-Covalent functionalized 5-FU conjugate was cytotoxic at $50 \mu \mathrm{g} / \mathrm{mL}$ post normalization with compound only control to negate precipitation observed with the compound. Cytotoxic effect graph of MWCNTS Covalent and Non-Covalent functionalized 5-FU Conjugate on HCT116 cells with out and with normalization given in figure 10a and 10b. Precipitation was observed and was found to interfere with the measurement of absorbance. The values were normalized with the absorbance values of the compound control and graph was plotted. Cytotoxicity of MWCNTs Covalent and Non-Covalent functionalized 5-FU conjugate was observed at $50 \mu \mathrm{g} / \mathrm{mL}$ and exhibited $65.78 \%$ cell death. The figure $11 \mathrm{a}$ shows no precipitation in cytotoxic images of Bevacizumab antibodies with HCT116 cells and in figure 11b the effect of Bevacizumab antibodies on HCT Cells depicted. Precipitation was observed in all 8 different concentrations of MWCNTs Covalent and Non-Covalent functionalized 5-Fluorouracil Bevacizumab Antibodies conjugate images depicts in figure 6a to 6h. MWCNTs Covalent and Non-Covalent functionalized 5Fluorouracil Bevacizumab Antibodies conjugate have great ability to exclusively identify cancer cell-surface receptors shows the precipitation. MWCNTs Covalent and Non-Covalent functionalized 5-Fluorouracil Bevacizumab Antibodies conjugate compound exhibited $\geq 80 \%$ cytotoxicity at 5 - Fluorouracil concentration $50 \mu \mathrm{g} / \mathrm{mL}$ and Bevacizumab Antibodies concentration $20 \mu \mathrm{g} / \mathrm{mL}$ post normalization with compound control to negate precipitation observed with the compound and demonstrated an $85.36 \%$ death. Cytotoxic effect graph of Covalent and Non covalent functionalized 5- Fluorouracil Bevacizumab Antibodies conjugate on HCT116 cells with out and with normalization given figure $12 \mathrm{a}$ and $12 \mathrm{~b}$ respectively.

It was observed that MWCNTs formulations demonstrated that the significant cell growth inhibitory to HCT116 cells in a concentration-dependent manner and growth inhibitory activity observed by precipitation. MWCNTs 5-Fluorouracil formulations for the delivery of 5-Fluorouracil with enhanced delivery efficiency into cancer cells by using a simple preparation method. Cytotoxicity of Functionalized MWCNTs 5 -Fluorouracil formulations were evaluated in HCT116 cells using MTT assays. It was shown that Functionalized MWCNTs 5 - Fluorouracil antibodies conjugates had much greater cytotoxicity compared to Functionalized MWCNTs 5 -Fluorouracil formulations without antibodies. This indicates that Functionalized MWCNTs 5 Fluorouracil Bevacizumab antibodies conjugates is potentially useful for the delivery of therapeutic agents (5 -Fluorouracil). The employment of nanomaterials can improve the pharmacokinetic properties of anticancer agents and provide effective and selective treatment for the soluble, reactive different functionalized MWCNTs formulations was used as the starting point to build multifunctional constructs with appended antibodies to effect specific targeting HCT116 cells, to carry and deliver 5 - Fluorouracil drug and to report location, respectively.

Cell cytotoxicity assay of all Functionalized MWCNTs 5-Fluorouracil formulations indicating a satisfying biocompatibility and antitumor activity. The ability to specifically target tumor cells invitro antibodies appended Functionalized MWCNTs constructs was encouraging and suggested. Fuctionalized MWCNTs 5-Fluorouracil Bevacizumab antibodies conjugate treatment is an effective inducer of a hypoxic environment, but the resulting cell kill and tumor shrinkage by precipitation is determined by the susceptibility of the cells.

Bevacizumab Antibodies along with chemotherapeutic agents binds to MWCNTs, attacks the cells more directly or connect with the HCT116 cells to deliver the treatment directly to the cancerous cells while avoiding healthy cells. All the functionalized MWCNTs 5 -Fluorouracil conjugates effects shown up to $72 \mathrm{hr}$ that confirms drug released in a sustained manner. 


\section{International Journal of Current Science Research and Review}

ISSN: 2581-8341

Volume 04 Issue 08 August 2021

DOI: 10.47191/ijcsrr/V4-i8-08, Impact Factor: 5.825

\section{REFERENCES}

1. Elhissi, AMA. Ahmed, W. Hassan, IU. Dhanak, VR. D'Emanuele, A. Carbon nanotubes in cancer therapy and drug delivery, J Drug Deliv 2012, pp. 1-10

2. Singla, N. and Singla, H. Novel role of nanotechnology in medicine, IJBR, 5(8), 2014, pp. 482- 486.

3. Yan, H. Xue, Z. Xie, J. Dong, Y. Toxicity of Carbon Nanotubes as Anti-Tumor Drug Carriers, Int J Nanomedicine, 14, 2019, pp. 10179-10194.

4. Saliev, T. The Advances in Biomedical Applications of Carbon Nanotubes. C, 5(29), 2019, pp. 1-22.

5. Miyashiro, D. Hamano, R. Umemura, K. A Review of Applications Using Mixed Materials of Cellulose, Nanocellulose and Carbon Nanotubes, J. Nanomater, 10(186), 2020, pp. 2-23.

6. Anzar, N. Hasan, R. Tyagi, M. Yadav, N. Narang, J. Carbon nanotube - A review on Synthesis, Properties and plethora of applications in the field of biomedical Science, Sensors International, 1, 2020, pp 1-10.

7. Hu, S. Wang, T. Pei, X. Cai, H. Chen, J. Zhang, X. Synergistic Enhancement of Antitumor Efficacy by PEGylated Multiwalled Carbon Nanotubes Modified with Cell-Penetrating Peptide TAT, Nanoscale Res Lett, 2016, pp. 1-14.

8. Wulan, P.P.D.K, Ulwani, S.H. Wulandari, H. Purwanto,W.W. Mulia, K. The effect of hydrochloric acid addition to increase carbon nanotubes dispersibility as drug delivery system by covalent functionalization, Mater. Sci. Eng. C, 2018, pp. 1-8.

9. Youssry, M. Al-Ruwaidhi, M. Zakeri, M. Zakeri, M. Physical functionalization of multiwalled carbon nanotubes for enhanced dispersibility in aqueous medium, emergent mater, 3 2020, pp, 25-32.

10. Pennetta, C. Floresta, G. Graziano, A.C.E. Cardile, V. Rubino, L. Galimberti, M. Functionalization of Single and MultiWalled Carbon Nanotubes with Polypropylene Glycol Decorated Pyrrole for the Development of Doxorubicin NanoConveyors for Cancer Drug Delivery, Nanomaterials, 10( 1073), 2020, pp. 1-22.

11. Das, R. Hamid, S.B.A. Ali, M.E. Annuar, M.S.M. Samsudin, E.M.B. Bagheri, S. Covalent Functionalization Schemes for Tailoring Solubility of Multi-Walled Carbon Nanotubes in Water and Acetone Solvents, Science of Advanced Materials, 8, 2016, pp. 1-12.

12. Garnica-Gutiérrez, R.L. Lara-Martínez, L.A. Palacios, E. Masso, F. Contreras, A. Hernández-Gutiérrez, S. Effect of Functionalized Carbon Nanotubes and their Citric Acid Polymerization on Mesenchymal Stem Cells In Vitro, Journal of Nanomaterials, 2018, pp. 1-12.

13. Le, V.T. Ngo, C.L. Le, Q.T. Ngo, T. Nguyen, D.N. Vu, M.T. Surface modification and functionalization of carbon nanotube with some organic compounds, Adv. Nat. Sci: Nanosci. Nanotechnol, 4, 2013, pp. 1-5.

14. Cendrowski, K. Jedrzejczak-Silicka, M. Carbon nanotubes with controlled length - preparation, characterization and their cytocompatibility effects, Pol. J. Chem. Tech, 20(2), 2018, pp. 71-79.

15. Ghoshal, S. Kushwaha, S.K.S. Srivastava, M. Tiwari, P. Drug Loading and Release from Functionalized Multiwalled Carbon Nanotubes Loaded With 6-Mercaptopurine Using Incipient Wetness Impregnation Method, American Journal of Advanced Drug Delivery, 2(2), 2014, pp. 213-223.

16. Ghoshal, S. Kushwaha, S.K.S. Tiwari, P. Srivastava, M. Comparative Loading and Release of 6-Mercaptopurine from Functionalized Multiwalled Carbon Nanotubes Using Various Methods, International journal of pharmacy and pharmaceutical research, 4(1), 2015, pp. 25-38.

17. Wang, C. and Li, W. Preparation, Characterization, and In Vitro and Vivo Antitumor Activity of Oridonin-Conjugated Multiwalled Carbon Nanotubes Functionalized with Carboxylic Group, J. Nanomater, 2016, pp. 1-7.

18. Wang, J.T.W, Spinato, C. Klippstein, R. Pach, E. Neutron-irradiated Antibodies functionalised carbon nanocapsules for targeted cancer radiotherapy, Carbon, 2020, pp. 1-31.

19. Buck, E. Sprick, M. Gaida, M.M. Grullich, C. Weber, T.F. Herpel, E. Tumor response to irinotecan is associated with CYP3A5 expression in colorectal cancer, Oncol. Lett, 17, 2019, pp. 3890-3898.

20. Lia, J. Yapb, S.Q. Yoongc, S.L. Nayaka, T.R. Chandraa, G.W. Angb, W.H. Carbon nanotube bottles for incorporation, release and enhanced cytotoxic effect of cisplatin, Carbon NY, 50(4), 2019, pp. 1625-1634.

21. Wang, J.T.W. Spinato, C. Klippstein, R. Pach, E. Neutron-irradiated Antibodiesfunctionalised carbon nanocapsules for targeted cancer radiotherapy, Carbon, 2020, pp. 1-31. 


\section{International Journal of Current Science Research and Review}

ISSN: 2581-8341

Volume 04 Issue 08 August 2021

DOI: 10.47191/ijcsrr/V4-i8-08, Impact Factor: 5.825

IJCSRR @ 2021

www.ijesrr.org

22. Buck, E. Sprick, M. Gaida, M.M. Grullich, C. Weber, T.F. Herpel, E. Tumor response to irinotecan is associated with CYP3A5 expression in colorectal cancer, Oncol. Lett, 17, 2019, pp. 3890-3898.

23. Mc Devitt, M.R. Chattopadhyay, D. Kappel, B.J. Jaggi, J.S. Schiffman, S.R. Antczak, C. Tumor targetting with antibodyfunctionalized, radiolabeled carbon nanotubes, J Nuclear Med, 2007; 48(7), pp. 1180-1189.

Cite this Article: Hemalatha K. P., Suresh V. Kulkarni, Manjunath K. (2021). HCT116 Cells Cytotoxic Response to Multifuctionalized 5- Fluorouracil MWCNTs Conjugates In Colorectal Cancer. International Journal of Current Science Research and Review, 4(8), 906-918 